\title{
THE ROLE OF DIRECT DEMOCRACY IN THE EUROPEAN UNION
}

\author{
LARS P. FELD \\ GEBHARD KIRCHGÄSSNER
}

CESIFO WORKING PAPER No. 1083

CATEgORy 2: Public Choice

NOVEMBER 2003

Presented AT CESIFo CONFERENCE “A CONSTITUTION FOR THE EUROPEAN UNION”, FEBRUARY 2003

\footnotetext{
An electronic version of the paper may be downloaded

- from the SSRN website:

- from the CESifo website:

www.SSRN.com

www. CESifo.de
} 


\title{
THE ROLE OF DIRECT DEMOCRACY IN THE EUROPEAN UNION
}

\begin{abstract}
In this paper, the introduction of direct-democratic decision-making in all EU decisions is considered when it is feasible without prohibitively increasing decision-making costs. We start with the contractarian argument that each constitution is a contract joining the citizens of a state and requires as such the explicit agreement of (a majority of) citizens. Thus, the future European Constitution as well as future changes of it should be decided by the European citizens. After a discussion of the pros and cons of direct democracy, the ability of direct democracy to help creating a European demos is discussed. Consequently, we propose a mandatory (required and binding) referendum on total and partial revisions of the European Constitution. In addition, we propose a constitutional initiative, a statutory and a general initiative as well as a fiscal referendum for financially important projects.
\end{abstract}

JEL Classification: D78.

Keywords: direct democracy, referenda, initiatives.

Lars P. Feld

Philipps-University of Marburg

Public Finance Group

Am Plan 2

35037 Marburg (Lahn)

Germany

feld@wiwi.uni-marburg.de
Gebhard Kirchgässner

University of St. Gallen

SIAW-HSG, Institutsgebäude

Dufourstr. 48

CH-9000 St. Gallen

Switzerland

Gebhard.Kirchgaessner@unisg.ch

We gratefully acknowledge financial support from the Swiss National Science Foundation (Grant-No. 5004-58524). We would like to thank Beat Blankart, Giuseppe Eusepi, Gianluigi Galeotti, Simon Hug, Dennis Mueller, and two anonymous referees for very valuable comments and suggestions. 


\section{Introduction}

The democratic deficit of the EU is legendary among legal scholars and political scientists. ${ }^{1}$ In its decision on the EU Treaty's compatibility with the German Basic Law (GG) in 1993, the German Constitutional Court argued that the EU lacks a comparable democratic legitimacy to the principle of democracy as it is fixed in the German constitution. German citizens' civil rights as laid down in Art. $38 \mathrm{GG}$ are not violated as long as the German parliament (Bundestag) exerts substantial decisionmaking powers. When EU treaties adopt explicit community competencies that are in conflict with those of nation states democratic accountability is however endangered. In several member states, among them the 'Eurosceptics' Denmark, Sweden and the U.K., but also France, the EU's democratic deficit has been similarly criticised. Indeed, the EU is essentially organised as a supranational authority of European executives despite its far-ranging competencies in European legislation. The influence of the European Parliament (EP) or of national parliaments is quite reduced. Moreover, Grande (2000) argues that members of the EP are too far removed from European citizens as to follow citizens' preferences or as to allow citizens to exert effective control of MEPs. Although the reduction of democratic control with regard to international organisations or international treaties is a general feature of modern governance, the unbalancing impact of the EU on the balance of powers in the member states is of particular importance (Abromeit 1998, p. 20).

In addition to these arguments, the German Constitutional Court in this decision and Grimm (1994), a former judge of the Court, argue that a fundamental condition for a treaty to be regarded as a constitution and thus also for the acceptance of the supremacy of EU law over national laws is the existence of a European public. Abromeit (1998, p. 32) calls this the 'no-demos thesis': A democracy can only be called such if it is based on a collective entity, the people or the nation, that is constituted by a common culture or common traditions and experiences. Since its creation, the EP faces the problem that the people of the member states have apparently not accepted it as the body that represents the interests of EU citizens. If the democratic deficit of the EU were reduced by giving the EP more legislative powers, a majoritarian decision in the EP would possibly not be accepted by the losing minority, in particular, when the minority is concentrated in one or several member states (Hug 2002, p. 110).

Several scholars have thus proposed the introduction of elements of direct democracy in EU decision-making in order to reduce the democratic deficit in the EU and to create a European demos. ${ }^{2}$ In his survey of the different policy proposals, Hug (2002, chap. 7) distinguishes required referenda (mandatory referenda), non-required referenda on government proposals (optional referenda) and non-required referenda on opposition proposals (initiatives). In most cases, scholars suggest to introduce elements of direct democracy without specifying in which instances a referendum should take place or under which circumstances an initiative should be allowed for. In cases a specification is made, required referenda are proposed for 'constitutional changes', i.e. changes of the treaties. A referendum decision on Eastern enlargement for example would fall into this category. In the cases,

1. See: Boyce (1993), Abromeit (1998, p. 4), Hug (2002, p.8) and for the following BVerfG 89, 1993, 155-213.

2. See: Bogdanor (1989), Opp (1994), Christiansen (1995), Körkemeyer (1995), Frey (1995), Schneider (1996), Zürn (1996, 2000), Epiney (1997), Weiler (1997, 1999), Abromeit (1998) and Papadopoulos (2002). 
where the majority requirement for required referenda is specified, scholars propose a 'double' majority of voters and of states. Non-required referenda are proposed to be triggered either by voters or by the EP. Hug criticises that the proposals are not discussed in comparing them with the existing decision-making procedures in order to find out to what extent the introduction of referenda and initiatives actually changes policy outcomes in the EU. But he abstains from proposing any blueprint direct democratic reform of EU decision-making. In Feld, Kirchgässner and Weck-Hannemann (2002), it is suggested to consider the introduction of 'budget referenda' in EU decision-making. On the one hand, the analysis follows the proposal of Hug by looking more closely on the impact of required referenda on budgetary outcomes in the EU, given its current budgetary process and the potential process after Eastern enlargement. On the other hand, the authors are not too realistic about the institutional provisions shaping the budget referendum. They suggest a general required referendum on the EU budget draft at the end of the current budgetary process with interactions of the Commission, the Council and the EP, totally abstracting from the transaction costs that this proposal involves. Naturally, a required referendum on the whole budget draft would unduly increase the time needed to pass a budget.

In this paper, our aim is to analyse to what extent direct democracy helps to resolve the democratic deficit at the EU level and to develop a European demos. In addition, we propose the introduction of referenda and initiatives in EU decision-making by going a step further towards realism. We consider direct democratic decision-making basically in all EU decisions, but develop proposals for its introduction only when it is feasible without prohibitively increasing decision-making costs. In Section 2, we clarify that each constitution is a contract joining the citizens of a state and requires as such the explicit agreement of (a majority of) citizens. In addition, we generally discuss the rationale of referenda and initiatives as instruments of control in a representative democracy and summarise empirical results on the impact of direct democracy on policy outcomes in Switzerland and the U.S. These arguments imply two different proposals for the EU in Section 3: First, the future European Constitution should also be approved by the European citizens once the Convention has proposed and the Intergovernmental Conference has agreed on the provisions of the Constitution. A basic consent of the European people is required to found a new federation. ${ }^{3}$ Second, future changes of the Constitution have to be decided by citizens in European referenda as well. In these two cases, we propose a mandatory (required and binding) referendum on total and partial revisions of the European Constitution. Third, a pre-specified number of citizens from a pre-specified number of countries should have the right to initiate constitutional changes at the EU level. In this case, we thus propose a popular initiative on partial revisions of the Constitution.

Given the current state of affairs, most of European politics would be covered by the proposed constitutional referendum and initiative. A look at the 'skeleton' for a EU constitution proposed by the Convention reveals however that only the first part contains provisions that are considered constitutional in the traditional sense. The second part of the draft treaty is supposed to contain statutes on the accomplishment of EU policy measures while the third part includes provisions for a continuity from the current Treaties to the new Constitution as well as on the adoption and revision of the Constitution. Requiring a referendum on the second part would restrict EU politics too strongly. We

3. See also: Let the people vote, in: THE ECONOMIST 367 (8325), May 24, 2003, pp. 10. 
therefore suggest to include the constitutional referendum only for the provisions that are currently proposed in the first part of the draft constitution. In Section 4, we discuss two additional institutional proposals. The first contains a statutory and a general initiative at the EU level. The second is a fiscal referendum for financially important EU projects. Concluding remarks follow in Section 5.

\section{The Pros and Cons of an Introduction of Referenda and Initiatives at the EU Level}

\subsection{The Necessity for Controlling Representatives at the Constitutional Level}

In De Republica, one of his main political texts, Cicero (59 B.C., 1988) defines three forms of government: Democracy as the rule of the people or the 'many', monarchy as the rule of a single principal, and aristocracy as the rule of an elite. By replicating the famous Aristotelian arguments (Politika III 8, 1280a2), Cicero argues that aristocracy, which he called the rule of the 'optimates', is the preferred way of government. Describing the time when Servius assumed power in Rome, he wrote that Servius "divided the people into property classes and constructed a voting system that gave the greatest number of votes to the rich and thus put into effect the principle which always ought to be adhered to in the commonwealth, that the greatest number should not have the greatest power." (Cicero 59 B.C., 1988, p. 149; quoted according to Gordon 1999, p. 112). Government by the people in these days meant government by a minority of property owners. In contrast to that, Cicero defined 'government by the masses' as an abortive development of the rule of the people, in the same way as dictatorship was defined being an unfavourable development of monarchy and oligarchy being a mutation of aristocracy. Government by the masses was called 'ochlocracy'.

This Aristotelian notion was already challenged during the Ancient World and later in the Middle Ages by philosophical contract theory. But it took until Enlightenment and the contributions by Hobbes, Locke, Rousseau and Kant that contract theory was fully developed as a justification for states (Höffe 1999, pp. 48). Rejecting any organic normative justification of the state, like the divine right of kings or natural law, political legitimacy is derived from a particular individual contract that is founding the law and the state. In a contractarian reconstruction of constitutions, the single human being (homo singularis) is the fundamental and decisive point of reference: What set of political rules benefits the greatest number of individuals in a group? ${ }^{4}$ In a Hobbesian initial situation, individuals are free to do what they want to. They are not restricted by any coercion from other individuals or statelike organisations. In the absence of state-like organisations, selfish individuals have however incentives to attempt at expropriating their fellow citizens which leads to the emergence of conflict. Buchanan (1975, p. 12) states the problem: "The issue is one of defining limits, and anarchy works only to the extent that limits among persons are either implicitly accepted by all or are imposed and enforced by some authority." In that situation, rational individuals will voluntarily subordinate to the law and to a coercive power, the state, that enforces the law, because it entails mutual benefits as compared to anarchy: Individual conflicts are resolved by an impartial third party such that individual property rights are secured to the largest possible extent. In addition, this newly created state helps to organise and enforce individual co-operation in the provision of collective goods that are as well to

4. For a comprehensive analysis of the contractarian approach to constitutions see Buchanan (1975, p. 5). 
the mutual benefit of a large number of individuals in a polity. The state helps to overcome free riding and to solve social dilemmas. The blueprint for such a voluntary agreement is found in a contract, in this case a basic initial one.

The early contractarians, Hobbes, Locke, Rousseau and Kant, as well as Rawls (1971) interpreted the contract theoretic reconstruction of the state as a thought experiment to find out to what set of political rules individuals could potentially agree. In contrast, following Wicksell (1896), proponents of constitutional political economy, like Buchanan (1975, pp. 147) or Buchanan and Tullock (1962, p. 96), emphasise the importance of a real and practical agreement of the citizens subordinating to a constitution. A coercive power of the state is as such legitimate only if agreement cannot be refused reasonably (Höffe 1999, p. 47) and agreement to a constitution (and to constitutional change) is explicit (Buchanan 1975, p. 148). The importance of such individual explicit agreement becomes obvious from the following argument. Hobbes conducted the contractarian thought experiment to justify the subordination to an absolute authority, but underestimated to what extent absolute power would corrupt: The authority itself has incentives to exploit citizens and to behave like a Leviathan. From that point of view, an indispensable need for constitutional rules follows that prevent the state, and the politicians, bureaucrats (and interest groups) that constitute it from abusing their power. The design of the constitution must take account of potentially disastrous political outcomes. "The passions of men will not conform to the dictates of reason and justice without constraint." (Hamilton, Federalist 15, according to Hamilton, Madison and Jay 1787/1788, p. 110). The government must hence subordinate itself to the rule of law. Checks and balances laid down in the constitution must help to create sufficient political competition such that dominant positions of specific centres of power in a polity cannot emerge.

Three basic institutions help to restrict state authorities such that they respect basic individual rights, do not assume illegitimately concentrated powers and follow the interests of the largest number of individual citizens in a jurisdiction (Höffe 1999, chap. 4): First, the rule of law must be secured by strong requirements for changes in basic rights and by an independent judiciary. Rights which can be changed arbitrarily cannot be interpreted as basic rights (Buchanan 1975, p. 106). Basic freedoms should not be changed easily by simple majorities in the legislature or of the people. Their change in contents should either be impossible or only partly allowed for under unanimity rule in order to prevent a suppression of structural (ethnic, linguistic, religious, racial) minorities by the majority. An independent judiciary ensures that these basic rights are secured even against the access of the state. Granting independence to the judiciary also indicates that government authorities subordinate to the rule of law which helps to turn state commitment to private property credible. Security of property rights induces private investment in human and physical capital and subsequently economic growth (Feld and Voigt 2003). Judiciary independence also contributes to enhancing political competition as a component of the checks and balances in a democracy.

Second, the separation and division of powers enhances political competition between centres of power. Since government is guided by natural persons who may surrender to the temptation of abusing power, caution requires division of powers between the executive, the legislative and the ju-

5. See Hume (1741), Popper (1945), Buchanan (1975). 
diciary. A separation of powers to the different state authorities puts them in a competitive situation such that they keep each other in check and subordinate themselves to each other. Third, democracy is a means to have political decisions oriented by the preferences of the individuals that are governed. Given that individuals voluntarily subordinate to a constitution, accept a limitation of their liberty and tolerate the partial coercion by the state, the citizens must have a say in political decision-making in order to have sufficient possibilities to control and sanction representatives.

Since the constitution provides the rules of the political game, it is too dangerous to enable representatives to determine the constitution without the explicit consent of the citizens. There is hence an inherent logic in the direct democratic decision of constitutional changes. Representatives should not have a final say on the rules that are supposed to impose restrictions on them. The competence competence to change the constitutional contract must be with those voluntarily subordinating to it. The case for direct democratic decision-making in particular on the constitutional level follows from the need to control representatives in order to enforce the preferences of citizens. It is this eternal fear of political philosophers and the more recent arguments by rational choice theorists that provide the basic argument for direct democracy. The same logic holds with respect to the foundation of a new federation by a new constitution as in the case of the European Union. This is even more important since the European Convention does not consist of independent wise men that have no interest in the constitutional rules they propose. The Convention is comprised of MEP's, members from national executives and legislatures, and members of the Commission. As Vaubel (2002) recently argued, it cannot be expected that these members of the Convention decide by abstracting from their individual interests. In this situation, the final acceptance of the European Constitution by the European people in a constitutional referendum is a necessary condition for a European federation to provide sufficient constitutional restrictions on EU representatives.

\subsection{Information, Control and Interest Groups}

Proposals of direct democracy are challenged by several arguments, the most important ones are the information and the interest group arguments. Direct democracy is supposed to have an informational disadvantage compared to representative democracy that originates from the division of labour between ordinary citizens and politicians (Kirchgässner, Feld and Savioz 1999, Feld and Kirchgässner 2000). Like people who allow their investment consultant discretion in financial decisions, they delegate decision-making power on political issues to political specialists who have a comparative advantage in doing politics. Delegation to representatives in the public sector occurs in order to save information costs. However, representatives then may have leeway to act opportunistically or in the partial interest of narrowly defined groups. A trade-off between agency costs and information cost savings occurs that can be resolved by organising political decision-making basically as a representative democracy, but allowing citizens to intervene selectively in politics by referenda and initiatives when political outcomes deviate unacceptably strongly from their interests. Referenda and initiatives serve as means to selectively control representatives between election years in a representative democracy. Whereas a pure representative democracy has an information advantage over direct democracy, referenda and initiatives allow to control representatives more strongly. 
While the referendum works as a veto of citizens against proposals from government and parliament, ${ }^{6}$ the initiative allows to propose new policies that are neglected by the political establishment, perhaps because they are not in their interest. In addition to referenda, initiatives enable citizens to an unbundling of policy packages created in the parliament via log-rolling agreements such that political outcomes that are against the interests of a majority of citizens are declined (Besley and Coate 2000). However, initiatives entail additional costs for citizens since they have to collect signatures to bring an initiative to the ballots. Depending on the signature requirement, the initiative will thus have a stronger or weaker impact on policy outcomes, the more or less easily issue unbundling may take place. Referenda and initiatives nevertheless induce a correction of political outcomes in favour of the preferences of the median voter, even in the case of strategic manipulation or agenda setting. ${ }^{7}$ As institutions of high control potential, referenda and initiatives are the more important, the further away representatives' decisions are from citizens. While informal control instruments may exist at the local level, they have to be replaced by formal institutions of control when political competencies are shifted to higher levels of government. At the EU level, elements of direct democracy can induce their most beneficial impact to force representatives to follow citizens' preferences. Aside the necessity of direct democracy to control representatives at the constitutional level, the first justification for proposing referenda and initiatives at the post-constitutional level in the EU thus follows again from the control argument.

This also holds despite the existence of asymmetric information in politics where representatives are better informed than citizens. Extending a model by Aghion and Tirole (1997), Marino and Matsusaka (2000) study budget procedures used in private and public decision-making. Starting from a situation where representatives have a bias towards higher spending, they analyse a decision-making procedure with full delegation in which representatives have full discretion about spending decisions and another one with partial delegation such that voters can veto or override a spending proposal ex post by a referendum. They show that in the partial delegation case, representatives have an incentive to supply biased information to citizens in order to obtain their approval for higher spending levels. Moreover, the authors show that these information biases can be severe such that full delegation dominates partial delegation. Since it turns out to be more difficult to distort information in large than in small projects, the optimal decision-making rule is one in which there is full delegation below a spending threshold such that routine projects are exclusively decided by representatives, and partial delegation above the spending threshold such that larger projects can be vetoed by voters. ${ }^{8}$

Grillo (1997) argues against the working of partial delegation in a polity of a bigger scale and of uncertain federal/confederate nature such as the EU. Decision-making and information costs are the more important, the larger a polity such that direct democracy is supposedly more feasible at the bcal or regional than at the national or supra-national level. The costs of conducting referenda and ini-

6. Citizens can use a (binding) referendum to reject government statutes or constitutional amendments. These can be mandatory or optional. An optional referendum takes place if a certain number of citizens asks for it.

7. For the first rigorous analysis of referenda see Romer and Rosenthal (1979), for a comprehensive analysis under perfect information see Steunenberg (1992). Easily accessible analyses are presented in Mueller (1996, p. 183), Feld and Kirchgässner (2001), Matsusaka (2002) and Feld and Matsusaka (2003).

8. See Kessler (2003) for such a summary of the Marino and Matsusaka model. 
tiatives are supposed to outweigh the benefits of additional control. Moreover, direct democratic decision-making is said not to be useful for decisions at the supranational level of a confederation because its potential for compromise is very much restrained. Binding compromises are however important in international organisations for mutual agreement of states on proposals in their mutual interests. Referenda and initiatives would then not allow for decisions in the long-term interest of a world order because citizens focus on their national interests.

The small scale argument is not completely convincing because the benefits at stake increase at least as much as the costs if direct democratic decision-making is introduced at higher levels of government. The agency problem is the more severe the higher the level of decision-making is in a federation. Potential deviations from citizens' interests lead to higher expected costs for these citizens at the national than at the local level because the importance of the political issues increases. Moreover, many countries, among them several European ones, also have a history of referenda for important constitutional changes. It is for example meanwhile common in the U.K. to have a referendum on the participation in additional steps of political integration in Europe. The legitimacy of such referenda is not challenged at all on grounds of a bigger scale polity. The higher organisational costs of conducting referenda and initiatives at the EU level as compared to the local level is also not convincing. Europewide referenda may pose additional organisational difficulties as compared to national referenda which could however be coped with in modern information societies. The confederation argument does not hold because the EU Treaty already has considerable elements of a federation. The more elements of a federation a polity has, the easier arguments for a direct participation of citizens in political decision-making can be made. From the perspective of optimal control of representatives, it is even necessary to introduce referenda and initiatives as control instruments as soon as the process of federation building starts.

There is a second asymmetric information case if representatives are imperfectly informed about citizens' preferences. Matsusaka (1992) argues that under such circumstances even benevolent politicians may impose policies that are deviating from citizens' wishes. Hence, they have incentives to propose a referendum whenever they are uncertain of citizens' wants in order to avoid being punished at the polls for enacting the wrong policy. The author provides evidence that referenda in California rather are on distributive issues than efficiency/ procedural issues. Referenda are also used in periods of political corruption to restrict government. This argument has implications for the EU. The further representatives are away from citizens, the less informed they are about citizens' political preferences, which holds more strongly in the EU than in the local case. Indeed, the EU is more strongly engaged in redistributive politics such that it pays off for EU representatives to elicit citizens' preferences via referenda.

The second argument of opponents against direct democracy is that imperfect and asymmetric information may provide opportunities for interest groups to unduly influence political outcomes in direct democracies. Matsusaka and McCarty (2001) analyse the case when interest groups are able to fool representatives. They use the threat of an initiative by pretending that their position is closer to citizens' preferences than the proposal of representatives, although this moves the policy outcome further away from the ideal point of the median voter. According to Gerber (1999), interest groups certainly influence outcomes in direct democracies, but they also have an impact on policy outcomes 
in representative democracies. Theoretically, and on the basis of piecemeal evidence, it is fully open whether interest group influence is stronger or less intense in direct than in representative democracies. Given this uncertainty, it is worth noting that there is systematic evidence, for the U.S. and Switzerland, that political outcomes are closer to citizens' preferences under direct than under representative democracy. Using aggregate data on Swiss cities in 1970, Pommerehne (1978) shows that the median voter model performs better in jurisdictions with referenda and initiatives. Gerber (1996, 1999) provides evidence for the U.S. strongly supporting Pommerehne's result. For two political issues, parental consent laws and capital punishment, she shows that initiatives correct policy outcomes towards the preferences of the median voter. Gerber (1996a) illustrates that the deviation of policy outcomes from citizens' preferences can be traced back to the influence of interest groups on representatives. Moreover, Feld and Schaltegger (2002) find evidence for the Swiss cantons that the influence of the state administration on federal matching grants is reduced by a fiscal referendum. This evidence supplements the control argument emphasised in favour of elements of direct democracy for the EU constitution. There is no reason to assume that referenda and initiatives should not similarly induce outcomes of EU policy to be closer to the preferences of EU citizens.

\subsection{Expressive Voting, Direct and Representative Democracy}

This may indeed be the problem because the information problem in democracies is a fundamental one. It is not simply captured by asymmetric information between representatives and voters. Because an individual citizen faces a low probability to influence voting outcomes, his/her instrumental benefit of participating in elections or referenda is much lower than the expected costs. From a rational choice perspective, voter turnout should therefore be low. The expected costs of participating in democratic decisions are the higher the better informed citizens have to be in order to obtain reflected political decisions. These information costs can be expected to be lower in representative than in direct democracy although incentives for supply and demand of information are higher in direct than in representative democracy (Kirchgässner, Feld and Savioz 1999, Feld and Kirchgässner 2000).

Despite the lack of incentives to show up at the ballots, voter turnout is considerably high in direct and representative democracies. In Britain, voter turnout amounted to an average of 74.1 percent in the 7 elections between 1970 and 1995 without any decreasing trend. While it was still 70.9 percent in 1997, it fell strongly to 59.4 percent in 2001. In Germany, it was 77.8 percent in 1990, 79.0 in 1994, 82.2 percent in 1998 and 80.6 percent in $2002 .^{9}$ In Switzerland, turnout in referenda and initiatives decreased since the 1950's when still 51 percent of citizens participated. Since the 1970's, it appears to have stabilised at around 40 percent on average. Elections of representatives at the Swiss federal level were at a 46.3 percent turnout on average in the last 20 years. ${ }^{10}$ In the U.S., turnout

9. In the seventies voter turnout was even higher than 90 percent in Germany, in the eighties, it was higher than 80 percent. See: Statistisches Jahrbuch 1997 für die Bundesrepublik Deutschland, pp. 90. For the British data see: Annual Abstract of Statistics, 1997, p. 75.

10. The exact figures are: 1979, 48.0, 1983: 48.9, 1987: 46.5, 1991: 46.0, 1995: 42.2. Source of the data: Schweizerisches Bundesamt für Statistik and W. Seitz, Nationalratswahlen 1995: Übersicht und Analyse, Bundesamt für Statistik, Bern 1997, p. 115. 
was at about the Swiss level: In the seven presidential elections between 1972 and 1996 it was 48.1 percent on average and 51.3 percent in 2000 . In midterm elections, it amounted to 35.5 percent with a minimum of 33.1 percent in $1990 .^{11}$ These turnouts cannot be explained by the rational actor approach as long as it takes only instrumental voting into account.

Brennan and Lomasky (1993) suggest to resolve this paradox by a theory of expressive voting. Accordingly, voters use elections to express their discontent with specific policies of a government, but also to show solidarity with particular policy platforms or to demonstrate a specific position, ideology or habit. Instead of being instrumental in the sense of an action to achieve a certain end as in the case of normal market transactions, voting would be expressive like people's cheering at a football match (Brennan and Hamlin, 2000, p. 130). If voting is expressive, there is a considerable concern that citizens vote irresponsibly by expressing their political preferences for or against general or particular policies because their voting decision may result from particular enthusiasms and prejudices. Brennan and Hamlin (2000, pp. 176) thus question that direct democracy will lead to an orientation of political decision-making at private or public interests. In contrast, they argue that pure representative democracy is a better procedure in a world of expressive voting because it allows to reduce the extent of irresponsible political outcomes by a selection of representatives. Voters are supposed to have a tendency to support candidates with relatively higher civic virtue because they cannot avoid forming and expressing opinions on candidates' competence and general political attractiveness. These opinions may be informed by moral codes individually obtained during socialisation of citizens. Reconstructing a basically Madisonian argument, representatives would hence be more public spirited, conscientious and competent than those whom they represent (Brennan and Hamlin, 2000, p. 180). As a result, people tend to be better judges of other people than they are of competing policy options.

The discussion of direct democracy by Brennan and Lomasky (1993) and Brennan and Hamlin (2000) is flawed for several reasons. First, the authors fully neglect the discussion process that precedes direct democratic decisions, but also elections. From their arguments, it appears as if citizens decide at the ballots after they have reflected on different proposals in isolation. In fact, decisions in referenda and initiatives take place in a totally different environment. Frey and Kirchgässner (1993), Kirchgässner, Feld and Savioz (1999) as well as Feld and Kirchgässner (2000) analyse the deliberation in direct democracy and characterise it as a relatively rational process which is the more intense, the more important a political decision is, and which is informed by the different positions of political parties, interest groups, but also by experts and less organised individuals. In the course of this discussion, a learning process occurs at least in parts of the citizenry. Since many citizens are confronted with the arguments of both sides, those opposing and those favouring a certain policy outcome, they are induced to consider each proposal anew. This can lead to a revision of their individual position. Therefore, the possibility also emerges that citizens examine the extent to which their preferences generalise. In addition, it can be presumed that citizens' willingness to bear costs of information acquisition is higher in direct legislation than in representative democracies. The reason for this is that it can become privately important for citizens to be well informed about political issues. Such a situation emerges if other citizens belonging to one's social network expect a citizen to be 
well informed on political issues and to go to the ballots to vote sincerely. The disappointment of this expectation leads to a loss of prestige. These private costs of being politically uninformed arise with respect to single political decisions, but not with respect to political parties. Private costs of political participation in direct democracy increase the individual incentives to vote according to their own interest, such that the extent of expressive motivation is lower in direct than in representative democracy.

Second, the hypothesis that representatives have higher civic virtue than those whom they represent can be fairly well challenged on the basis of experience with most democratically elected governments and assemblies in OECD countries. Brennan and Hamlin (2000, p. 178) may be right in asserting that the relevant virtues need not coincide with prejudices. It is perhaps more important that representatives behave virtuously in the sense of not exploiting citizens, instead of subscribing to a certain morally informed sexual behaviour. However, the cases of corruption in France, Germany, the U.K., Italy and so on in the last two decades as compared to Switzerland and U.S. states illustrate that representative democracies are not able to select more virtuous representatives; the amount of corruption does not seem to depend on whether the citizens have direct political rights or not. Somehow the authors seem to hang onto the old dream of selecting statesmen instead of politicians. German speaking economists often bemoan that a statesman like Ludwig Erhard, the first German Minister of Economics after the War, has not been in sight for years in Germany. ${ }^{12}$ That voters might fail to select more virtuous representatives may result from the false implicit assumption that they can more easily judge people than policies. People may more easily appeal to individual emotions than policies ever can. If for example beauty matters as much for the election of representatives as it does for hiring in the labour market, beautiful representatives have ceteris paribus less restrictions to extract political rents.

Third, the authors exaggerate their expressive voting argument. It is not fully convincing that citizens express their opinion at the ballots in the same fashion as cheering at a football match. Mueller (2003, p. 321) notes that it is at least equally likely that citizens use the opportunity to express more noble sentiments. "Norms that govern conduct toward others might be expected to be particularly likely to come into play when individuals vote." (Mueller, 2003, p. 321). Kirchgässner (1992, 1996) argues that voting is a low cost decision by which citizens do neither affect their own instrumental well-being nor the well-being of other individuals but the collective outcome. In such a low cost decision it is cheaper to act along moral sentiments than in market decisions where moral behaviour is potentially punished by utility maximising individuals. The theory of low cost decisions hence provides a competing argument why people vote and additional arguments why voting is guided by moral codes. The possibility that the discourse preceding the referendum decision at the ballots may lead to a revision of preferences over policies plays a special role in that respect. Citizens may act more altruistically in referenda and initiatives than in economic decisions. For example, Pommerehne and Schneider (1985) presented empirical evidence that Swiss people vote for redistributional programmes despite the fact that these result in a loss in their own wealth. In decisions at the ballots, voters therefore may follow an ethical position to a larger extent than could be expected on the basis of the preferences that guide their behaviour in the market place. This effect can be traced back to

12. See, e.g., Vaubel (1988). 
the discourse preceding a decision at the ballots. At least a temporary revision of citizens' evaluations of policies is feasible, increasing the probability that common interests will guide the social choice. Direct democracy hence may provide even a better chance for the development of civic virtues than representative democracy.

\subsection{Direct Democracy and a European demos}

Connected to the role of discussion in direct democracy, the introduction of referenda and initiatives at the EU level is sometimes supposed to have an additional indirect advantage. As mentioned in the introduction, one of the most often criticised shortcomings of EU decision-making is the lack of a European demos interpreted as a common European political conscience of the citizens in the individual member states. ${ }^{13}$ Elements of direct democracy at the EU level are supposed to lead to the formation of a European demos. This might help to develop a common policy understanding. In this case, Switzerland is again an inspiring example. After the Swiss civil war in 1847, a federal state was created which could not rely on a national demos: A Swiss demos did not exist then. Only cantonal demoi could be observed. According to Hug (2000, chap. 6), the elements of direct democracy in the Swiss constitution contributed to the development of a Swiss demos.

Hug (2000) also outlines clearly, however, that the hopes of an EU-wide referendum forming an EU demos should not be exaggerated. Two caveats in drawing an analogy between $19^{\text {th }}$ century Switzerland and the EU are particularly in place: First, elements of direct democracy might be helpful but are neither necessary nor sufficient for a European demos to emerge. It is too little known about the mechanisms that lead citizens to overthrow positions that are based on their narrow (national or cantonal) interests and instead adopt more general positions (Cederman and Kraus, 2003). For Switzerland, the empirical results on differences in tax evasion between cantons with and without referenda indicate that a referendum might shape such a transformation of interests. It might, however, also be that national interests prevail and are exacerbated by EU-wide referenda for instance if referendum outcomes frequently follow along the distinction between poor and rich member countries. Second, it is obvious that at least in some member countries citizens are not yet ready to accept majority decisions at the EU level. Consider for instance an increase in tax rates in order to finance additional funds for Eastern European countries on a larger scale. Within the single member states, such a regional redistribution, say from Northern Italy to the Mezzogiorno, is (more or less) accepted by the citizens paying for it because a national feeling of mutual solidarity exists. At the European level, a corresponding consciousness is still lacking. Thus, at the moment a corresponding proposal would probably be rejected by the people.

However, like in Switzerland in the $19^{\text {th }}$ century, the introduction of referenda could help to develop such a consciousness which might help that in the long run redistributional measures would be accepted by the European citizens also at the European level. Like central bank independence is neither necessary nor sufficient but helpful for price stability, the discourse among citizens that precedes

13. See the more recent discussions in several European newspapers on the development of a European demos in light of the geopolitical developments after the second Iraq war: J. DERRIDA and J. HABERMAS, Unsere Erneuerung, in: FRANKFURTER ALLGEMEINE ZEITUNG No. 125, May 31, 2003, p. 33. 
the referendum or initiative decisions at the EU level helps to transform individual self-interest of citizens to a public interest and the national to European public interests. The nationally informed positions of citizens may be questioned according to what extent they can be generalised to the European level. In order to make such reflected political decisions at the EU level, citizens need incentives to discuss European issues. Referenda and initiatives at the EU level are a convenient way to provide them.

\subsection{The Wicksellian Connection between Public Services and Tax Prices}

The most convincing argument for the introduction of instruments of direct democracy at the EU level stems from the fact that referenda and initiatives allow to conduct public policy such that the tax prices citizens pay for public goods and services are linked to the benefits the citizens obtain from these public goods and services. Breton (1996) calls this the Wicksellian (1896) connection. The systematic empirical analyses of the impact of referenda and initiatives on economic policy for Switzerland and the U.S. states provide strong support for the hypothesis that the Wicksellian connection rather exists in direct than in representative democracy. ${ }^{14}$ According to these studies, public spending, ${ }^{15}$ revenue ${ }^{16}$ and debt $^{17}$ are significantly lower in jurisdictions with direct democracy than in those with pure representative democracy. With respect to spending structure, the fiscal referendum mainly restricts welfare and administrative spending according to Schaltegger (2001) and Vatter and Freitag (2002). With respect to revenue structure both, the U.S. states with initiatives and the Swiss cantons with a fiscal referendum, rely more on user charges than on broad-based taxes. ${ }^{18}$ Moreover, Matsusaka (1995, 2002) and Schaltegger and Feld (2001) provide evidence that centralisation of spending and revenue is reduced by the referendum.

The question remains, however, whether the lower level of public spending also leads to a more efficient public sector. Pommerehne (1983) analysed costs and prices of local garbage collection in 103 Swiss cities in 1970. He found that average refuse collection costs (per household) were - ceteris paribus - lowest in cities with direct legislation and private garbage collection. For a panel of the Swiss cantons from 1970 to 1996, Barankay (2002) reports significantly lower infant mortality rates and a higher share of college degrees in more direct democratic cantons suggesting that this indicates a higher quality of public goods in the cantons. Pommerehne and Weck-Hannemann (1996) show that in those Swiss cantons in which citizens have an impact on budgetary policy in direct legislation, tax evasion is - ceteris paribus - lower as compared to the average of the cantons without such direct influence. ${ }^{19}$ These results are corroborated by Feld and Frey (2002a) and by Torgler (2002)

14. For earlier descriptions of these studies, see Kirchgässner, Feld and Savioz (1999, chap. 5), Feld and Kirchgässner (2000, 2001) and Matsusaka (2002).

15. See Matsusaka $(1995,2000,2002)$ for the U.S. and Feld and Kirchgässner (1999, 2001), Feld and Matsusaka (2003), Schaltegger (2001) and Vatter and Freitag (2002) for Switzerland.

16. See Matsusaka (1995, 2000, 2002) for the U.S. and Feld and Kirchgässner (2001) for Switzerland.

17. See Kiewiet and Szakaly (1996) for the U.S. and Feld and Kirchgässner (1999, 2001, 2001a) for Switzerland.

18. See Matsusaka (1995) for the states and Feld and Matsusaka (2003a) for the Swiss cantons.

19. There are also theoretical arguments why citizens in direct democracies evade taxes to a lesser extent than those in representative democracies. See Pommerehne, Hart and Feld (1997) and Feld and Frey (2002). 
using different data sets. If, however, the willingness to pay taxes is the higher the more satisfied citizens are with public services supplied, then these results are evidence for a higher satisfaction of citizens and, therefore, for greater efficiency of the provision of public services. Indeed, Frey and Stutzer $(2000,2002)$ present evidence that people in Switzerland perceive themselves as more satisfied with their life as a whole in direct democratic cantons keeping income levels and other controls constant. These results are evidence for the stronger link between tax prices and public services in direct democracy. They indicate as well that Swiss citizens feel more responsible for their community. They might be more willing to accept decisions that lead to an income or wealth loss for themselves than citizens of representative democracies.

These studies lend support for the hypothesis that direct democratic systems are more efficient than representative democratic ones. A more efficient political system should also lead to better economic performance. Feld and Savioz (1997) study the relationship between budgetary referenda and economic performance of Swiss cantons measured by GDP per employee. In a panel with annual data from 1984 to 1993 for the 26 Swiss cantons, they arrive at the conclusion that GDP per employee is - ceteris paribus - by about 5 percent higher in those cantons with budgetary referenda compared to cantons without those referenda. Again there is corroborating evidence from Freitag and Vatter (2000) for Switzerland and by Blomberg and Hess (2002) for the U.S. states. All in all, the empirical evidence from the U.S. and Switzerland supports the hypothesis that (economic) policy outcomes in jurisdictions with referenda and initiatives are more closely orientated at the Wicksellian connection of spending and tax prices. Given this evidence, much is really speaking for the introduction of direct democracy in the future EU constitution.

\section{A Mandatory Referendum on the European Constitution}

Given the success of referenda and initiatives in the U.S. and Switzerland and the necessity to have a constitutional referendum at the EU level in order to control the rules of the political game, we therefore propose to include a mandatory constitutional referendum for the EU Constitution. This proposal contains two components: First, the basic document, the founding treaty that will be the EU constitution, must be adopted in a mandatory referendum. Second, future changes of the EU constitution have to be finally adopted by the European citizenry in a mandatory referendum as well. These referenda should be binding and required. The EU institutions involved in the decisions on the EU Constitution, the Commission, the Council and the EP, cannot abrogate or overrule the referendum decision other than proposing a new amendment to the constitution (second case) or proposing a new constitution draft (first case). The EU citizenry empowered to decide on EU constitutional issues is as defined in Art. 5 of the first part in the current draft constitution as of 28 October 2002.

Both constitutional referenda, the first founding referendum and the second referendum on constitutional changes, are adopted if a simple majority of citizens and a qualified (two thirds) majority of countries accept the constitution or the constitutional amendment, respectively. Like Frey (1995), Schneider (1996), Epiney (1997) and Papadopoulos (2002), we thus also propose a 'double' ma- 
jority of voters and member countries. ${ }^{20}$ While the first two authors do not specify the required majorities, the third proposes to have a majority of voters and a qualified majority of at least 10 member states. Papadopoulos' proposal corresponds to ours. Currently, Epiney's proposal also corresponds to the proposal in this paper, but our proposal is dynamically stable to Eastern and any further enlargement. Compared to Abromeit's (1998) proposal, the one made here is less restrictive. Abromeit suggests to have a majority of voters in all states which translates the current unanimity requirement for Treaty changes in the Council and the parliaments of the representative democratic EU member states to an EU decision-making structure with direct democracy. This would, however, give every single member state extreme veto power, provide incentives for strategic behaviour and, therefore, make changes nearly impossible. ${ }^{21}$ Thus, it is reasonable to reduce the quorum with respect to the member states to two thirds. No other restriction with respect to the majority requirement should be imposed. Especially, there must be no requirement that the referendum is adopted only if turnout exceeds a certain threshold of the EU citizenry, because such a quorum invites strategic behaviour and is actually a quorum on the share of approval votes. ${ }^{22}$ No such quorum should hence exist.

The first founding referendum should be on the whole new Treaty that contains the three sections of the actual Constitution, of the policy areas and the general and concluding provisions. The mandatory referendum should not extend to the normal statutes of the EU, it should only be on constitutional changes. According to the current draft, proposed by the Convention, the mandatory constitutional referendum thus covers title III on the assignment of powers of the EU, title IV on EU institutions, title $\mathrm{V}$ on procedures to decide EU policy measures, title VI on the democratic principle, title VII on the finances of the EU, title VIII and IX on EU foreign policy, and title X on entry to and exit from the EU. In addition, the mandatory constitutional referendum should be used for changes of the final section that contains the provisions for the adoption of the new Constitution and the procedures to change the Constitution. The mandatory constitutional referendum does not interfere with the provisions under title I on the structure of the constitution and under title II on EU citizenship and basic rights. The substance of both titles should not be changed by any decision-making body (eternity clause). The mandatory referendum on the adoption of the new Constitution should be included in the article in the final section that is supposed to contain provisions on the adoption of the Constitution. In the draft of 29 October 2002, this article is called Art. $x+4$. The mandatory constitutional referendum should be laid down in Art. $x+3$ on the procedures for changes of the Constitution in the same section.

20. For a very useful summary of the different proposals for direct democracy in the EU see again Hug (2002, chap. 7, pp. 102). The comparisons of our proposals with the ones in the literature in Sections 3 and 4 are based on his summary.

21. In the current situation log-rolling can help to overcome such blocking. This is, however, hardly possible if the final decisions are taken by popular referenda.

22. See for this the experiences in the Weimar Republic, in the Bundesland Hamburg as well as in Italy discussed in Kirchgässner, Frey and Savioz (1999, pp. 6, 38f., 161). 
If the European Court were turned into a constitutional court, it should have the obligation to check the compatibility of proposed changes of the constitution with the substance of title II. ${ }^{23}$ This check should be performed before the referendum takes place, independent of whether the change is proposed by the parliament or, as is discussed below, by a popular initiative. In this proposal, we follow Buchanan (2001) who objects against extending a mandatory constitutional referendum on all constitutional provisions. There is a potential conflict between the rule of law and the principle of democracy that can most easily be resolved by formally protecting basic human and civil rights from democratic access. Buchanan (2001) acknowledges however the usefulness of a mandatory constitutional referendum in preserving the property rights granted in the constitution. The referendum includes the European citizens as an additional veto player in the EU decision-making game such that once agreed upon, constitutional outcomes are stabilised. Constitutional changes are more difficult though not impossible. Moser (1996, 1996a) shows this stability enhancing effect of the referendum theoretically in spatial voting models. With respect to the constitutional draft of the Convention, this is particularly important with respect to the assignment of competencies to the EU. A creeping centralisation, as criticised by Vaubel (1994) and Blankart (2000), is thus less probable. ${ }^{24}$

\section{Constitutional/Statutory Initiatives and a Fiscal Referendum at the EU Level}

\subsection{Constitutional and Statutory Initiatives at the EU Level}

While the referendum is an institution that enhances the stability of constitutional and policy outcomes and is thus relatively conservative, the popular initiative grants citizens the possibility to put new political issues on the agenda or to have an unbundling of policy issues. In both functions, the initiative is innovative. It creates new policies or modifies existing policies. The inclusion of an initiative in EU decision-making in addition to the mandatory constitutional referendum is thus useful in order to facilitate the launching of new policies which are neglected by the political elite for the citizens. The initiative accomplishes this goal at relatively low costs compared to the foundation of new parties and is thus also a valve for political protest: In a direct democracy, citizens can oppose the political establishment by using political institutions instead of political unrest on the streets.

This leads to propose the introduction of a constitutional and a statutory initiative in the EU Constitution. The constitutional initiative serves the purpose of introducing institutional innovation at the EU level. The EU will develop further to a federation and may at some point in time have much stronger competencies than it has today. Although the mandatory referendum will decelerate this process, it will not (and should not) prevent it if it is reasonable and serves the interests of a majority of EU citizens and a qualified majority of the countries. A more powerful Union will need additional finances,

23. Please note that this check should only occur with respect to the Bill of Rights of the European Constitution. In addition, there must be a control that there is a unity of contents of the proposed changes of the European Constitution. This means that no disparate issues should be allowed to be combined in order to succeed at the ballots. See also Papadopoulos (2002). The role of the constitutional court should not be as active as that of the U.S. Supreme Court or the German Constitutional Court.

24. In contrast to Vaubel (1996), we hence trust more strongly in the centralisation reducing impact of the constitutional referendum following the arguments by Blankart (2000) and the empirical results by Schaltegger and Feld (2001). 
will seek additional spending opportunities and will have a much higher frequency of EU legislation than today. In such a (utopian?) political environment, citizens may see the necessity to have additional instruments, like an optional statutory referendum to control EU legislation, at their disposal. Naturally, the constitutional initiative can also be used to assign additional competencies to the EU or to launch a new policy, a new 'fund', to propose the enlargement by a new member state and so on.

In contrast to Schneider (1996), Epiney (1997) and Abromeit (1998), we thus dismiss the possibility of including an optional statutory referendum in the EU Constitution. The reason is mainly a pragmatic one: The optional referendum would unduly reduce the efficiency of EU decision-making and increase decision-making costs very strongly. Either the optional referendum would be relatively easily accessible to a small number of citizens such that partial interests could slow down EU decisionmaking considerably. Or access would be prohibitively high such that the optional referendum could be declined anyway. Abromeit (1998) suggests to have an optional referendum on regional (sectoral) objects that could be triggered by 5 percent of the voters of that region (50'000 voters in a sector) and would come into force when a simple majority of voters in that region (in that state) adopted it. This proposal gives a strong veto power to regional or sectoral interests that might well be against the interests of a majority of EU citizens. Epiney (1997) augments a proposal by Zürn (1996, 2000) that the European Parliament should be able to trigger an optional referendum. According to this proposal, it would be triggered by an absolute majority of MEP's that represent at least 5 states. It would cover all directives and regulations and would be accepted if simple majorities of voters and states adopted it. This proposal would unduly strengthen the EP in the balance of EU powers and induce a plebiscite element in EU decision-making. Plebiscites have in common that they are demanded by the legislature or the executive and are thus at their disposal. Very often they are used strategically as the French experience in particular (as well as the German experience in the 1930's) shows. Such provisions should not play a role in EU decision-making. Finally, Schneider (1996) proposes an optional constitutional referendum that is triggered by 5 million EU citizens and must be adopted by majorities of voters and states if a turnout of 30 percent is reached. In particular the turnout quorum poses problems in this proposal because, as is stated above, it invites strategic behaviour of opponents of a certain constitutional proposal. ${ }^{25}$ The necessity for an optional constitutional referendum does also not exist, if there is a mandatory constitutional referendum: Any change of the constitution must be decided by EU citizens such that a selective constitutional veto becomes obsolete.

Our proposal of a constitutional initiative is more cautious than the optional (statutory) referendum with respect to the efficiency of the EU decision-making and the openness to give partial interests an instrument for slowing down decisions. It is more ambitious than the referendum at the EU level in general with respect to the preconditions for directly conducting EU politics. Abromeit (2002, pp. 201) objects against an EU initiative basically with the same argument as her proposal of optional statutory referendum is rejected here: Initiatives would allow partial interests undue influence. In addition, the initiative poses the question of a proper formulation of constitutional amendments and legal statutes.

25. Papadopoulos (2002) also proposes a participation requirement that has the same problems. 
Abromeit's basic argument against the initiative is unconvincing. An initiative is necessarily intensively discussed already before it is actually launched. During the phase of signature collection, many people have to be convinced to subscribe to an initiative. When the signature collection is successful, the legislature (EP and Council) and the executive (Commission and Council) have ample opportunities to discuss and criticise the popular initiative. In addition, they can have a right for a counterproposal that includes useful parts of the initiative or provides a more reasonable alternative to citizens. It should be realised as well that a new innovative policy or an institutional innovation in the case of constitutional initiatives is much more difficult to accomplish than a veto on a proposal by the legislature or the executive. Risk-averse people are status quo oriented. This orientation plays against the initiative, but for the veto via an optional referendum. Indeed, the empirical evidence from the U.S. and Switzerland supports this argument. As mentioned in Section 2, partial interests, in particular financially important interest groups, in the U.S. have difficulties to succeed with an initiative compared to citizen groups, while money is influential in stopping policies by using a referendum. The experience with initiatives in Switzerland is hinting in the same direction: The majority of the federal initiatives are rejected. However, an initiative influences policy in many cases even when it is declined: The political elite realises that it has neglected particular political issues to an unjustified extent and corrects this.

All in all, the inclusion of a constitutional and statutory initiative in the European Constitution is useful and helps to develop the EU institutionally and politically. With respect to the constitutional initiative we propose that EU citizens as defined in the constitution as well as official authorities like the EP, the Commission, or particular parties can trigger an initiative if they are able to collect signatures that make up for 5 percent of the electorate. According to Matsusaka's (1995) study for the U.S., a signature requirement of 10 percent of the electorate and more, prevents the initiative from having a significant impact on (fiscal) policy outcomes. The median signature requirement for the popular initiative at the U.S. state level is 5 percent. When Switzerland included a constitutional initiative in 1891, the signature requirement for it was 5 percent of the electorate as well. Because it was fixed at the absolute number of 50'000 signatures and only once increased to 100'000 after the women got their voting rights, the threshold for an initiative has become much lower today. Alternatively, the signature requirement could consider the representation of member countries much more strongly such that (in addition) a signature requirement of 15 percent of the electorate in 5 countries, but 2 percent of the electorate at least, may also be sufficient. ${ }^{26}$

There is much less research however on the time allowed to collect signatures. Even a low signature requirement of 2 percent of the EU electorate might be unduly restrictive if only a month were allowed to collect them. A look at the Swiss cantonal level might be helpful in this case. With the exception of the canton of St. Gallen no difference in collection time is made with respect to constitutional and statutory initiatives. While citizens have two months to collect signatures in Nidwalden and the Ticino, they have 18 months in Solothurn. St. Gallen allows three months for signature collection in the case of the statutory initiative and six months for the constitutional initiative. Nine cantons don't have any restriction. At the EU level, more time to collect signatures is of course needed than at the

26. Papadopoulos (2002) proposes similar provisions for an EU initiative. He suggests a signature requirement of 5 percent of the electorate in at least 5 member countries. 
Swiss cantonal level. Thus, the restriction of collection time should be about 18 months or two years to give an initiative committee sufficient time to collect signatures representing a fair share of citizens from different member countries. The EU constitution must also ensure that collection of signatures is not locally concentrated in order to hinder an organised suppression of people willing to sign for an initiative. Much of the German experience with direct democracy in the Weimar Republic teaches that signature collection should not be concentrated in officially fixed administrative buildings. It appears to be much better to allow for a collection in public places in general as most U.S. states and Switzerland have it.

The constitutional initiative is adopted if a majority of citizens and a qualified (two thirds) majority of countries is reached. Unlike the mandatory referendum, the jurisdiction of the constitutional initiative is not a priori restricted in the domain of basic human and civil rights. It should be possible to extend to human rights. However, both the constitutional and statutory initiative are subject to judicial control ex ante. Constitutional amendments and laws resulting from the initiative can be abrogated when they contradict basic human and civil rights. Like the mandatory constitutional referendum, the constitutional initiative should be laid down in Art. $x+3$ on the procedures for changes of the Constitution in the final section.

The provisions for the statutory initiative are the same as for the constitutional initiative as regards who can propose an initiative and the signature requirement. However, the statutory initiative will be accepted if only a majority of citizens adopts it. Again, the Parliament or the Council are allowed to formulate a counterproposal to a statutory initiative ex ante. The European Court has again the obligation to check the compatibility of the statutory initiative with constitutional provisions before the ballot takes place. Moreover, it should also be possible to make a 'general initiative' where the initiative describes a specific political objective and it is the role of the (Council and/or the) Parliament to formulate the corresponding law. The statutory as well as the general initiative should be included under title VI of the Constitution on the democratic 'life' of the Union. A new article must be created that includes the provisions for them. In addition, the principle of participatory democracy, as currently considered in the draft constitution of the Convention, should explicitly include elections, referenda and initiatives as means for democratic participation.

Two detailed proposals for an EU initiative exist. Although constitutional and statutory initiatives are not distinguished, but instead formulated for abstract general rules, Epiney (1997) proposes that 10 percent of the citizens in at least 5 states or the governments of 5 states can trigger an initiative that is adopted by the double majority of voters and countries. Weiler $(1997,1999)$ proposes a statutory initiative that is triggered by citizens in at least 5 member states (without specifying how many citizens) and is adopted as well by the double majority. Compared to the proposed constitutional initiative in this paper, both have relatively low signature and majority requirements. In our proposal, the majority requirement for the statutory initiative is with a simple majority of citizens, relatively low.

\subsection{A Fiscal Referendum at the EU Level}

Given the mandatory constitutional referendum, the constitutional and the statutory initiative, the question emerges whether the EU Constitution will then contain sufficient safeguards to bind EU 
representatives to the preferences of EU citizens. In the U.S. states and the Swiss cantons, this question is negatively replied to. Most of them have additional provisions for a direct influence of citizens on public finances. As the survey in Section 2 indicates, most of the empirical results are indeed obtained for fiscal referenda. Does the EU Constitution need a fiscal referendum as well? In order to be able to answer that question, two things should be discussed. First, a fiscal referendum must be defined. Following the most common Swiss definition, a fiscal referendum consists of three components (or a combination of them): If government and parliament propose a spending project that exceeds a certain spending threshold, an optional or mandatory fiscal referendum is triggered. In addition, specific fiscal referenda can exist with respect to changes in taxation or with respect to new bonds that are used to finance the spending project.

Second, it must be discussed how European policy domains should be financed. In Kirchgässner (1994) it is argued that EU spending should be financed by proportional (indirect) taxes, but not by (progressive) personal income taxes. The rationale behind this proposal lies in the different control possibilities which exist on different governmental levels. Any government will act the more in accordance with the preferences of the individuals, the more the citizens are able to control it. At the lower levels, in smaller jurisdictions, the citizens have better possibilities to force the government to act according to their preferences. In this respect, there exists a significant difference between progressive (direct) and proportional (indirect) taxes. If tax rates can only be changed via changing a law, which is the usual way in the case of indirect taxes, a relative increase of the government share has to be decided via the parliamentary process or via a referendum. This ensures a public discussion, and at least as long as government seeks its re-election, it will hesitate to increase taxes, and it faces difficulties in getting such approved by the parliament, not to mention the general public. Thus, increases of indirect tax rates are comparatively rare events, even with respect to quantity taxes, whose real yield is eroded due to inflation. Such proportional taxes leave a relatively small leeway for Leviathan behaviour of a government. Progressive direct taxes, on the other hand, create larger revenue not only whenever private economic activity and - consequently - private income increases, but also as long as inflation prevails, if there is no corresponding indexation. Thus, there is seldom a need for a change of the tax law if the government wants to collect higher revenue: It gets it automatically. Therefore, progressive taxes provide a comparatively wide leeway for a government to behave as a Leviathan.

This implies that the necessity of control possibilities differs with respect to different taxes. For taxes whose revenue raises (nearly) automatically there is more need of controllability compared to (indirect) taxes where it is most difficult for politicians to increase the (relative) revenue: Much more control by the citizens is needed to keep down direct taxes than to restrict indirect, especially general sales taxes like the VAT. Therefore, at the European level only the revenues from indirect taxes should be available. We hence propose to fix a rate of a VAT surcharge on national VAT revenue in the EU Constitution that is equivalent to the revenue the EU now gets from the VAT resource. This surcharge should already be included in the proposed EU Constitution that is to be decided in the founding mandatory constitutional referendum according to our proposal. Given that there should be a mandatory constitutional referendum on each constitutional change, each change of that surcharge rate has to be decided by citizens in a referendum as well. When there are no constitutional changes that degrade financial constitutional provisions to mere statutes, no tax referendum is needed. Simi- 
larly, no referendum on new bonds is needed as long as the principle of a balanced budget is fixed as in Art. 39 of the draft constitution. If there are changes in both constitutional provisions, for whatever reason, specific fiscal referenda on tax changes and the issuing of new bonds should be introduced in the EU constitution. The majority requirement should then be the same as for the mandatory constitutional referendum.

With respect to EU spending, the draft constitution does not contain any specific provisions. Indirectly, however, spending is pre-determined by the assignment of tasks to the EU level. The current EU budget, though following the principle of unity, can be (politically) divided in different funds, the agricultural and the structural funds. Again, the mandatory constitutional referendum suffices as long as the assignment of new responsibilities is as closely attached to spending as it currently is at the EU level. If, again for whatever reason, the EU should adopt more competencies and power and thus also have increased spending needs, a fiscal referendum for new spending projects would however be useful. In that case, we propose to have an optional and a mandatory fiscal referendum on new spending projects with different spending thresholds. The thresholds could be in absolute or relative terms. Moreover, the spending threshold should also differ whether it is a non-recurring project or recurring expenditure. Due to the fact, however, that there is no need for such a referendum at the moment, it does not make sense to specify exactly these four different thresholds. The majority requirement could be a simple majority of EU citizens. It must be noted that such a fiscal referendum is useful if the EU would develop to a more powerful Union. Because constitutional provisions are created for a longer time horizon, a fiscal referendum may thus already be considered to be included today. We believe however that the current financial structure of the EU and the constitutional provisions thought about according to the draft constitution of the Convention do not necessarily need to be restricted additionally by a fiscal referendum. Given the current state of the discussion, a mandatory constitutional referendum as well as a constitutional and statutory and general initiatives appear to be sufficient to bind EU policy outcomes to the preferences of EU citizens.

\section{Summary and Concluding Remarks}

In this paper, the introduction of direct democratic decision-making in all EU decisions is considered when it is feasible without prohibitively increasing decision-making costs. After clarifying that each constitution is a contract joining the citizens of a state and requires as such the explicit agreement of (at least a majority of) citizens, the pros and cons of direct democracy from a theoretical and empirical perspective are discussed. That citizens have better possibilities to control representatives in direct than in representatives democracies provides one of the strongest arguments for the introduction of direct democracy in the European Constitution. The control argument cannot be invalidated by the consideration of interest group or scale arguments. That citizens may vote expressively is no argument against direct democracy as well. It can rather be expected that expressive voting leads citizens to express moral sentiments instead of narrow self-interests at the ballots. Seen from this perspective, referenda and initiatives may be an institutionalised way to shape the emergence of a European demos. If this happens to be the case, it is another argument for the introduction of referenda and initiatives at the EU level. A final strong argument for direct democracy in this paper is obtained from the comparative empirical evidence on economic policy outcomes in direct and representative demo- 
cratic jurisdictions according to which policies in direct democracy more strongly follow the Wicksellian connection of tax prices and spending.

These arguments lead us to propose the introduction of elements of direct democracy in a future European Constitution. The European citizens should have the possibility to decide themselves about the future European Constitution as well as any future changes of it. Thus, we propose a mandatory, required and binding referendum on total and partial revisions of the European Constitution. Because we also propose that the EU gets its own value added tax revenue, the rate of which is to be fixed in the constitution, tax increase is also subject to the mandatory referendum. In addition, we propose a constitutional initiative, a statutory as well as a general initiative. Finally, in the case that the EU should adopt more competencies and power and, therefore, have increased spending needs, we propose a fiscal referendum for financially important projects.

\section{References}

Abromeit, H. (1998). Democracy in Europe: Legitimising Politics in a Non-State Polity, Berghahn, New York.

Abromeit, H. (2002). Wozu braucht man Demokratie?: Die postnationale Herausforderung der Demokratietheorie, Leske and Budrich, Opladen.

Aghion, Ph. and J. Tirole (1997). Formal and real authority in organizations, Journal of Political Economy 105, 1-29.

Aristoteles. Politika, edited by H. Flashar, Akademie Verlag, Berlin 1879.

Barankay, I. (2002), Referendums, Citizens' Initiatives and the Quality of Public Goods: Theory and Evidence, mimeo, University of Warwick.

Besley, T. and St. Coate (2000). Issue unbundling via citizens' initiatives, mimeo, London School of Economics.

Blankart, C.B. (2000). The process of government centralization: A constitutional view, Constitutional Political Economy 11, 27 - 39.

Blomberg, S.B. and G.D. Hess (2002). The impact of voter activity on economic activity, forthcoming in: European Journal of Political Economy.

Bogdanor, V. (1989). Direct elections, representative democracy and European integration, Electoral Studies 8, $205-216$.

Boyce, B. (1993). The democratic deficit of the European Community, Parliamentary Affairs 46, 458 $-477$.

Brennan, G. and A. Hamlin (2000). Democratic Devices and Desires, Cambridge University Press, Cambridge.

Brennan, G. and L. Lomasky (1993). Democracy and Decision: The Pure Theory of Electoral Preference, Cambridge University Press, Cambridge.

Breton, A. (1996). Competitive Governments: An Economic Theory of Politics and Public Finance, Cambridge University Press, Cambridge.

Buchanan, J.M. (1975). The Limits of Liberty: Between Anarchy and Leviathan, University of Chicago Press, Chicago.

Buchanan, J.M. (2001). Direct democracy, classical liberalism, and constitutional strategy, Kyklos 54, Special Issue 'Festschrift on the occasion of the $60^{\text {th }}$ birthday of Bruno S. Frey', $235-242$. 
Buchanan, J.M. and G. Tullock (1962). The Calculus of Consent: Logical Foundations of Constitutional Democracy, University of Michigan Press, Ann Arbor.

Cederman, L.-E. and P.A. Kraus (2003), Transnational Communication and the European Demos, mimeo, Harvard University.

Christiansen, T. (1995). Gemeinsinn und Europäische Integration: Strategien zur Optimierung von Demokratie- und Integrationsziel, in: W. Steffani and U. Thaysen (eds.), Demokratie in Europa: Zur Rolle der Parlamente, Westdeutscher Verlag, Opladen, 50 - 64.

Cicero (59 B.C., 1988). De re publica and De legibus, Translation by C.W. Keyes, Harvard University Press, Cambridge.

Epiney, A. (1997). Le référendum européen, in: A. Auer and J.-F. Flauss (eds.), Le référendum européen, Bruylant, Bruxelles, $287-315$.

Feld, L.P. and B.S. Frey (2002). Trust breeds trust: How taxpayers are treated, Economics of Governance 3, $87-99$.

Feld, L.P. and B.S. Frey (2002a). The tax authority and the taxpayer: An exploratory analysis, mimeo, University of St. Gallen 2002.

Feld, L.P. and G. Kirchgässner (1999). Public debt and budgetary procedures: Top down or bottom up? Some evidence from Swiss municipalities, in: J.M. Poterba and J. von Hagen (eds.), Fiscal Institutions and Fiscal Performance, Chicago University Press, Chicago 1999, 151 - 179.

Feld, L.P. and G. Kirchgässner (2000). Direct democracy, political culture and the outcome of economic policy: A report on the Swiss experience, European Journal of Political Economy 16, 287 -306 .

Feld, L.P. and G. Kirchgässner (2001). The political economy of direct legislation: Direct democracy and local decision-making, Economic Policy 16 (33), 329 - 367

Feld, L.P. and G. Kirchgässner (2001a). Does direct democracy reduce public debt? Evidence from Swiss municipalities, Public Choice 109, 347 - 370.

Feld, L.P. and J.G. Matsusaka (2003). Budget referendums and government spending: Evidence from Swiss cantons, forthcoming in: Journal of Public Economics.

Feld, L.P. and J.G. Matsusaka (2003a). The political economy of tax structure: Some panel evidence for Swiss cantons, mimeo, University of St. Gallen.

Feld, L.P. and M.R. Savioz (1997). Direct democracy matters for economic performance: An empirical investigation, Kyklos 50, $507-538$.

Feld, L.P. and Ch.A. Schaltegger (2002). Voters as hard budget constraints: On the determination of intergovernmental grants, mimeo, Philipps-University of Marburg.

Feld, L.P. and S. Voigt (2003). Economic Growth and Judicial Independence: Cross Country Evidence Using a New Set of Indicators, forthcoming in: European Journal of Political Economy 19.

Feld, L.P., G. Kirchgässner and H. Weck-Hannemann (2002). Enlargement and the European budget: Budgetary decision-making and fiscal constraints, in: B. Steunenberg (ed.), Widening the European Union: The Politics of Institutional Change and Reform, Routledge, London, 144 - 162.

Freitag, M. and A. Vatter (2000). Direkte Demokratie, Konkordanz und Wirtschaftsleistung: Ein Vergleich der Schweizer Kantone, Schweizerische Zeitschrift für Volkswirtschaft und Statistik 136, $579-606$.

Frey, B.S. (1995). A directly democratic and federal Europe, Constitutional Political Economy 7, 267 -279 .

Frey, B.S. and G. Kirchgässner (1993). Diskursethik, Politische Ökonomie und Volksabstimmungen, Analyse und Kritik 15, 129 - 149. 
Frey, B.S. and A. Stutzer (2000). Happiness, economy and institutions, Economic Journal 110, 918 938.

Frey, B.S. and A. Stutzer (2002). Happiness and Economics, Princeton University Press, Princeton/Oxford.

Gerber, E.R. (1996). Legislative response to the threat of initiatives, American Journal of Political Science 40, 99 - 128.

Gerber, E.R. (1996a). Legislatures, initiatives, and representation: The effects of state legislative institutions on policy, Political Research Quarterly 49, 263 - 286.

Gerber, E.R. (1999). The Populist Paradox: Interest Group Influence and the Promise of Direct Legislation, Princeton University Press, Princeton.

Gordon, S. (1999). Controlling the State: Constitutionalism from Ancient Athens to Today, Harvard University Press, Cambridge 1999.

Grande, E. (2000). Post-national democracy in Europe, in: M.T. Greven and L.W. Pauly (eds.), Democracy Beyond the State? The European Dilemma and the Emerging Global Order, Rowman and Littlefield, Lanham, 115 - 138.

Grillo, M. (1997). Democracy, competition and the principle of Isonomia: An economic analysis pf the political exchange as an incomplete contract, in: A. Breton, G. Galeotti, P. Salmon and R. Wintrobe (eds.), Understanding Democracy: Economic and Political Perspectives, Cambridge University Press, New York, 47 - 63.

Grimm, D. (1994). Braucht Europa eine Verfassung?, Olzog, München.

Hamilton, A., J. Madison and J. Jay (1787/1788). The Federalist Papers, Bantam Books, New York 1982.

Hobbes, Th. (1651, 1991). Leviathan or the Matter, Form and Power of a Commonwealth, Ecclesiastical and Civil, Cambridge University Press, Cambridge 1991.

Höffe, O. (1999). Demokratie im Zeitalter der Globalisierung, Beck, München.

Hug, S. (2002). Voices of Europe: Citizens, Referendums and European Integration, Rowman and Littlefield, Lanham.

Hume, D. (1741). That politics may be reduced to a science, in: Essays: Moral, Political and Literary, reprinted by: Liberty Classics, Indianapolis 1985, $14-31$.

Kant, I. Grundlegung zur Metaphysik der Sitten, in: Königlich-Preussische Akademie der Wissenschaften (ed.), Gesammelte Schriften, Band IV, Berlin 1902, 385 - 463.

Kessler, A. (2003). Representative versus direct democracy: The role of informational asymmetries, CEPR Discussion Paper No. 3944, May 2003; forthcoming in: Public Choice (2003).

Kiewiet, D.R. and K. Szakaly (1996). Constitutional limitations on borrowing: An analysis of state bonded indebtedness, Journal of Law, Economics and Organization 12, 62 - 97.

Kirchgässner, G. (1992). Towards a theory of low-cost decisions, European Journal of Political Economy 8, 305 - 320.

Kirchgässner, G. (1994). Constitutional economics and its relevance for the evolution of rules, Kyklos 47, $321-339$.

Kirchgässner, G. (1996). Bemerkungen zur Minimalmoral, Zeitschrift für Wirtschafts- und Sozialwissenschaften 116, 223 - 251.

Kirchgässner, G., L.P. Feld and M.R. Savioz (1999). Die direkte Demokratie: Modern, erfolgreich, entwicklungs- und exportfähig, Helbing and Lichtenhahn, Basel.

Körkemeyer, S. (1995). Direkte Demokratie und Europäische Integration: Zu den Möglichkeiten und Grenzen unmittelbarer Volksbeteiligung an der staatlichen Willensbildung in der Euro- 
päischen Union, dargestellt am Beispiel der Schweiz, unter Berücksichtigung der Rechtslage in den derzeitigen EU-Mitgliedstaaten, Stämpfli, Bern.

Locke, J. (1689). Two Treatises of Government, Cambridge University Press, Cambridge 1970.

Marino, A.M. and J.G. Matsusaka (2000). Decision processes, agency problems, and information: An economic analysis of budget procedures, mimeo, University of Southern California, Los Angeles.

Matsusaka, J.G. (1992). Economics of direct legislation, Quarterly Journal of Economics 107, 541 571.

Matsusaka, J.G. (1995). Fiscal effects of the voter initiative: Evidence from the last 30 years, Journal of Political Economy 103, 587 - 623.

Matsusaka, J.G. (2000). Fiscal effects of the voter initiative in the first half of the twentieth century, Journal of Law and Economics 43, 619 - 650.

Matsusaka, J.G. (2002). For the Many or the Few: How the Initiative Process Changes American Government, book manuscript, University of Southern California, Los Angeles.

Matsusaka, J.G. and N.M. McCarty (2001). Political resource allocation: Benefits and costs of voter initiatives, Journal of Law, Economics, and Organization 17, 413 - 448.

Moser, P. (1996). Why is Swiss politics so stable?, Schweizerische Zeitschrift für Volkswirtschaft und Statistik 132, $31-60$.

Moser, P. (1996a). Zwischen Immobilität und Instabilität: Auswirkungen der Einführung der allgemeinen Volksinitiative und der Verfassungsgerichtsbarkeit in der Schweiz, Schweizerische Zeitschrift für Politische Wissenschaft 2, 233 - 255.

Mueller, D.C. (1996). Constitutional Democracy, Oxford University Press, Oxford.

Mueller, D.C. (2003). Public Choice III, Cambridge University Press, Cambridge.

Opp, K.-D. (1994). The role of voice in a future Europe, Kyklos 47, 385 - 402.

Papadopoulos, Y. (2002). Peut-on imaginer d'organiser des référendums à l'échelle européenne et à quelles conditions?, mimeo, University of Lausanne.

Pommerehne, W.W. (1978). Institutional approaches to public expenditure: Empirical evidence from Swiss municipalities, Journal of Public Economics 9, 255 - 280.

Pommerehne, W.W. (1983). Private versus öffentliche Müllabfuhr - nochmals betrachtet, Finanzarchiv 41, $466-475$.

Pommerehne, W.W. and F. Schneider (1985). Politisch-ökonomische Überprüfung des Kaufkraftinzidenzkonzepts: Eine Analyse der AHV-Abstimmungen von 1972 und 1978, in: E.A. Brugger and R.L. Frey (eds), Sektoralpolitik vs. Regionalpolitik, Diessenhofen, Rüegger, 75 - 100.

Pommerehne, W.W. and H. Weck-Hannemann (1996). Tax rates, tax administration and income tax evasion in Switzerland, Public Choice 88, 161 - 170.

Pommerehne, W.W., A. Hart and L.P. Feld (1997). Steuerhinterziehung und ihre Kontrolle in unterschiedlichen politischen Systemen, Homo oeconomicus 14, 469 - 487.

Popper, K. (1945). The Open Society and Its Enemies, Vol. I: The Spell of Plato, Routledge, London.

Rawls , J.A. (1971). A Theory of Justice, Harvard University Press, Cambridge.

Romer, Th. and H. Rosenthal (1979). Bureaucrats versus voters: On the political economy of resource allocation by direct democracies, Quarterly Journal of Economics 93, 563 - 587.

Rousseau, J.-J. Du contrat social ou principes du droit politique, in: Euvres complètes, Band III, Gallimard, Paris 1959, $349-470$. 
Schaltegger, Ch.A. (2001), The effects of federalism and democracy on the size of government: Evidence from Swiss sub-national jurisdictions, ifo Studien 47, 145 - 162.

Schaltegger, Ch.A. and L.P. Feld (2001). On government centralization and budget referendums: Evidence from Switzerland, CESifo Working Paper No. 615, December 2001.

Schneider, F. (1996). The design of a minimal European Federal Union: Some ideas using the Public Choice approach, in: J.C. Pardo and F. Schneider (eds.), Current Issues in Public Choice, Edward Elgar, Cheltenham, 203 - 220.

Steunenberg, B. (1992). Referendum, initiative and veto power: Budgetary decision-making in local government, Kyklos 45, 501 - 529.

Torgler, B. (2002). Tax morale and institutions, forthcoming in: European Journal of Political Economy.

Vatter, A. and M. Freitag (2002). Die Janusköpfigkeit von Verhandlungsdemokratien: Zur Wirkung von Konkordanz, direkter Demokratie und dezentraler Entscheidungsstrukturen auf den öffentlichen Sektor der Schweizer Kantone, Swiss Political Science Review 8, 53 - 80.

Vaubel, R. (1988). Möglichkeiten einer erfolgreichen Beschäftigungspolitik, in: H. Scherf (ed.), Beschäftigungsprobleme hochentwickelter Volkswirtschaften, Duncker und Humblot, Berlin 1989, 17 35.

Vaubel, R. (1994). The political economy of centralization and the European Community, Public Choice 81, $151-190$.

Vaubel, R. (1996). Constitutional safeguards against centralization in federal states: An international cross - section analysis, Constitutional Political Economy 7, 79 - 102.

Vaubel, R. (2002). Die Politische Ökonomie des Europäischen Verfassungskonvents, Wirtschaftsdienst 82, 636- 640 .

Weiler, J.H.H. (1997). The European Union belongs to its citizens: Three immodest proposals, European Law Review 22, 150 - 156.

Weiler, J.H.H. (1999). The Constitution of Europe: "Do the New Clothes Have an Emperor?" and Other Essays on European Integration, Cambridge University Press, Cambridge.

Wicksell, J. (1896). Finanztheoretische Untersuchungen nebst Darstellung und Kritik des Steuerwesens Schwedens, Gustav Fischer, Jena.

Zürn, M. (1996). Über den Staat und die Demokratie im europäischen Mehrebenensystem, Politische Vierteljahresschrift 37, 27 - 55.

Zürn, M. (2000). Democratic governance beyond the nation-state: The EU and other international nstitutions, European Journal of International Relations 6, 183 - 221. 


\section{CESifo Working Paper Series}

(for full list see www.cesifo.de)

1016 J. Stephen Ferris and Stanley L. Winer, Searching for Keynes: With Application to Canada, 1870-2000, August 2003

1017 Massimo Bordignon, Luca Colombo and Umberto Galmarini, Fiscal Federalism and Endogenous Lobbies' Formation, August 2003

1018 Annette Alstadsæter, The Dual Income Tax and Firms' Income Shifting through the Choice of Organizational Form and Real Capital Investments, August 2003

1019 Peter Fredriksson and Bertil Holmlund, Optimal Unemployment Insurance Design: Time Limits, Monitoring, or Workfare?, August 2003

1020 Kashif S. Mansori, Following in their Footsteps: Comparing Interest Parity Conditions in Central European Economies to the Euro Countries, August 2003

1021 Christoph Borgmann and Matthias Heidler, Demographics and Volatile Social Security Wealth: Political Risks of Benefit Rule Changes in Germany, August 2003

1022 Kjell Erik Lommerud, Bjørn Sandvik and Odd Rune Staume, Good Jobs, Bad Jobs and Redistribution, August 2003

1023 Patrick Karl O'Brien, The Governance of Globalization: The Political Economy of Anglo-American Hegemony, 1793-2003, September 2003

1024 Antonio Ciccone and Giovanni Peri, Skills' Substitutability and Technological Progress: U.S. States 1950-1990, September 2003

1025 Bjørn Sandvik, Optimal Taxation and Normalisations, September 2003

1026 Massimo Bordignon and Gilberto Turati, Bailing Out Expectations and Health Expenditure in Italy, September 2003

1027 José A. Herce, Namkee Ahn, Ricard Génova, and Joaquín Pereira, Bio-Demographic and Health Aspects of Ageing in the EU, September 2003

1028 John Komlos and Marieluise Baur, From the Tallest to (One of) the Fattest: The Enigmatic Fate of the American Population in the $20^{\text {th }}$ Century, September 2003

1029 Stefan Napel and Mika Widgrén, Bargaining and Distribution of Power in the EU's Conciliation Committee, September 2003

1030 Kai Li and Dale J. Poirier, Relationship Between Maternal Behavior During Pregnancy, Birth Outcome, and Early Childhood Development: An Exploratory Study, September 2003 
1031 Ivar Ekeland, James J. Heckman, and Lars Nesheim, Identifcation and Estimation of Hedonic Models, September 2003

1032 Kjetil Bjorvatn and Alexander W. Cappelen, Decentralization and the Fate of Minorities, September 2003

1033 Lars-Erik Borge and Jørn Rattsø, The Relationships Between Costs and User Charges: The Case of a Norwegian Utility Service, September 2003

1034 Maureen Were and Nancy N. Nafula, An Assessment of the Impact of HIV/AIDS on Economic Growth: The Case of Kenya, September 2003

1035 A. Lans Bovenberg, Tax Policy and Labor Market Performance, September 2003

1036 Peter Birch Sørensen, Neutral Taxation of Shareholder Income: A Norwegian Tax Reform Proposal, September 2003

1037 Roberta Dessi and Sheilagh Ogilvie, Social Capital and Collusion: The Case of Merchant Guilds, September 2003

1038 Alessandra Casarico and Carlo Devillanova, Capital-skill Complementarity and the Redistributive Effects of Social Security Reform, September 2003

1039 Assaf Razin and Efraim Sadka, Privatizing Social Security Under Balanced-Budget Constraints: A Political-Economy Approach, September 2003

1040 Michele Moretto, Paolo M. Panteghini, and Carlo Scarpa, Investment Size and Firm's Value under Profit Sharing Regulation, September 2003

1041 A. Lans Bovenberg and Peter Birch Sørensen, Improving the Equity-Efficiency Tradeoff: Mandatory Savings Accounts for Social Insurance, September 2003

1042 Bas van Aarle, Harry Garretsen, and Florence Huart, Transatlantic Monetary and Fiscal Policy Interaction, September 2003

1043 Jerome L. Stein, Stochastic Optimal Control Modeling of Debt Crises, September 2003

1044 Thomas Stratmann, Tainted Money? Contribution Limits and the Effectiveness of Campaign Spending, September 2003

1045 Marianna Grimaldi and Paul De Grauwe, Bubbling and Crashing Exchange Rates, September 2003

1046 Assar Lindbeck and Dennis J. Snower, The Firm as a Pool of Factor Complementarities, September 2003

1047 Volker Grossmann, Firm Size and Diversification: Asymmetric Multiproduct Firms under Cournot Competition, September 2003

1048 Dan Anderberg, Insiders, Outsiders, and the Underground Economy, October 2003 
1049 Jose Apesteguia, Steffen Huck and Jörg Oechssler, Imitation - Theory and Experimental Evidence, October 2003

1050 G. Abío, G. Mahieu and C. Patxot, On the Optimality of PAYG Pension Systems in an Endogenous Fertility Setting, October 2003

1051 Carlos Fonseca Marinheiro, Output Smoothing in EMU and OECD: Can We Forego Government Contribution? A Risk Sharing Approach, October 2003

1052 Olivier Bargain and Nicolas Moreau, Is the Collective Model of Labor Supply Useful for Tax Policy Analysis? A Simulation Exercise, October 2003

1053 Michael Artis, Is there a European Business Cycle?, October 2003

1054 Martin R. West and Ludger Wößmann, Which School Systems Sort Weaker Students into Smaller Classes? International Evidence, October 2003

1055 Annette Alstadsaeter, Income Tax, Consumption Value of Education, and the Choice of Educational Type, October 2003

1056 Ansgar Belke and Ralph Setzer, Exchange Rate Volatility and Employment Growth: Empirical Evidence from the CEE Economies, October 2003

1057 Carsten Hefeker, Structural Reforms and the Enlargement of Monetary Union, October 2003

1058 Henning Bohn and Charles Stuart, Voting and Nonlinear Taxes in a Stylized Representative Democracy, October 2003

1059 Philippe Choné, David le Blanc and Isabelle Robert-Bobée, Female Labor Supply and Child Care in France, October 2003

1060 V. Anton Muscatelli, Patrizio Tirelli and Carmine Trecroci, Fiscal and Monetary Policy Interactions: Empirical Evidence and Optimal Policy Using a Structural New Keynesian Model, October 2003

1061 Helmuth Cremer and Pierre Pestieau, Wealth Transfer Taxation: A Survey, October 2003

1062 Henning Bohn, Will Social Security and Medicare Remain Viable as the U.S. Population is Aging? An Update, October 2003

1063 James M. Malcomson, Health Service Gatekeepers, October 2003

1064 Jakob von Weizsäcker, The Hayek Pension: An efficient minimum pension to complement the welfare state, October 2003

1065 Joerg Baten, Creating Firms for a New Century: Determinants of Firm Creation around 1900 , October 2003 
1066 Christian Keuschnigg, Public Policy and Venture Capital Backed Innovation, October 2003

1067 Thomas von Ungern-Sternberg, State Intervention on the Market for Natural Damage Insurance in Europe, October 2003

1068 Mark V. Pauly, Time, Risk, Precommitment, and Adverse Selection in Competitive Insurance Markets, October 2003

1069 Wolfgang Ochel, Decentralising Wage Bargaining in Germany - A Way to Increase Employment?, November 2003

1070 Jay Pil Choi, Patent Pools and Cross-Licensing in the Shadow of Patent Litigation, November 2003

1071 Martin Peitz and Patrick Waelbroeck, Piracy of Digital Products: A Critical Review of the Economics Literature, November 2003

1072 George Economides, Jim Malley, Apostolis Philippopoulos, and Ulrich Woitek, Electoral Uncertainty, Fiscal Policies \& Growth: Theory and Evidence from Germany, the UK and the US, November 2003

1073 Robert S. Chirinko and Julie Ann Elston, Finance, Control, and Profitability: The Influence of German Banks, November 2003

1074 Wolfgang Eggert and Martin Kolmar, The Taxation of Financial Capital under Asymmetric Information and the Tax-Competition Paradox, November 2003

1075 Amihai Glazer, Vesa Kanniainen, and Panu Poutvaara, Income Taxes, Property Values, and Migration, November 2003

1076 Jonas Agell, Why are Small Firms Different? Managers' Views, November 2003

1077 Rafael Lalive, Social Interactions in Unemployment, November 2003

1078 Jean Pisani-Ferry, The Surprising French Employment Performance: What Lessons?, November 2003

1079 Josef Falkinger, Attention, Economies, November 2003

1080 Andreas Haufler and Michael Pflüger, Market Structure and the Taxation of International Trade, November 2003

1081 Jonas Agell and Helge Bennmarker, Endogenous Wage Rigidity, November 2003

1082 Fwu-Ranq Chang, On the Elasticities of Harvesting Rules, November 2003

1083 Lars P. Feld and Gebhard Kirchgässner, The Role of Direct Democracy in the European Union, November 2003 